(four or more). There was some suggestion in this study that women having their first labour may be slightly more likely to be induced than others, but no evidence that induction was greater for high parity women. Of course, individual hospitals or consultants may have definite patterns, but overall no clearcut differences emerged.

The observation that induced babies were the expected weight for their gestation is similar to the finding from the survey of British Births $1970^{* 1}$ for births at term or later. That study reported that those induced earlier in pregnancy were more likely to be "small for dates." There was no evidence of such a difference in this study, but numbers induced before the 38th week were small.

While women who were induced had shorter labours than those going into labour spontaneously and they were also more likely to receive pain relief, the assessment of pain levels and of the duration of bad pain was similar in the two groups. So too were their views of their labour experience. Nevertheless, there is no doubt that most women think that spontaneous labour is preferable.

Generally, women are conservative in that they tend to opt for the things they have experienced. This holds particularly for home births but also for hospital births and for having or not having epidural analgesia. It does not hold for those who had an induction, mainly because induction was perceived as "unnatural.'”

The observation that comparatively few women in social class $\mathrm{V}$ were induced merits further research. A small-for-dates fetus is commonly regarded as a major indication for induction and is more likely to occur among these women.
I am indebted to the mothers who answered the questions, my colleagues, particularly Maureen O'Brien, members of the Institute's Advisory Committee, and others. The study was funded by the Department of Health and Social Security.

\section{References}

${ }^{1}$ Department of Health and Social Security, On the State of the Public Health for the Year 1975. London, HMSO, 1976.

2 Tipton, R H, and Lewis, N V, British Medical fournal, 1975, 1, 391.

British Medical fournal, 1976, 1, 787.

' Fedrick, J, and Yudkin, P, British Medical fournal, 1976, 1, 738.

'Chalmers, I, et al, British Medical fournal, 1976, 1, 735.

${ }^{6}$ Chalmers, I, Lawson, J G, and Turnbull, A C, British fournal of Obstetrics and Gynaecology, 1976, 83, 921 and 930.

Yudkin, P, British fournal of Obstetrics and Gynaecology, 1976, 83, 603.

${ }^{8}$ Cole, R A, Howie, P W, and Macnaughton, M C, Lancet, 1975, 1, 767.

${ }^{9}$ McNay, M B, et al, British Medical fournal, 1977, 1, 347.

${ }^{10}$ Bonnar, J, British Medical fournal, 1976, 1, 651.

11 Turnbull, A, Daily Mail, 30 June, 1976.

1:2 Richards, M P M, Social Science and Medicine, 1975, 9, 595.

${ }^{13}$ Dunn, P M, Lancet, 1976, 1, 790.

${ }^{14}$ Gillie, L, and Gillie, O, Sunday Times, 13 October 1974.

15 Walker, P A, Martin, R H, and Higgingbottom, J, Lancet, 1972, 2, 374

${ }^{16}$ Richards, M P M. In press.

17 Lewis, B V, Rana, S, and Crook, E, Lancet, 1975, 1, 1197.

${ }^{18}$ Kitzinger, S, Submission to the Department of Health and Social Security from the National Childbirth Trust, 1975.

${ }^{19}$ Beard, R, et al, The Management of Labour. London Royal College of Obstetricians and Gynaecologists, 1975.

2" Baird, D, Lancet, 1960, 2, 557 and 609.

21 Chamberlain, R, et al, British Births 1970. London, Heinemann, 1975.

\title{
Patients' attitudes to induction and labour
}

\author{
PETER STEWART
}

British Medical fournal, 1977, 2, 749-752

\begin{abstract}
Summary
An attempt was made to ascertain patients' attitudes towards planned induction and labour. Twenty per cent of patients had not heard of induction before their pregnancy, and those who had had most probably heard about it from relations and friends rather than the media. Most patients had no firm opinions on induction of labour but were usually glad to have their pregnancy ended. Many considered that they had not been given enough information by the medical staff on their induction. The amount of pain experienced by patients at amniotomy was related to the "favourability" of the cervix. Possibly women with a low cervical score should be given more premedication or inhalation analgesia at amniotomy. Most patients found injections of narcotic agents adequate analgesia in labour. Those patients who did not receive adequate analgesia were principally those who had either very short or quite long labours.

Patients with long labours may benefit from more liberal use of analgesia, but no satisfactory form of analgesia seems to be available for patients who are likely to deliver within two or three hours of induction.
\end{abstract}

Nuneaton Maternity Hospital, Nuneaton, Warwickshire

PETER STEWART, BM, DOBSTRCOG, registrar

\section{Introduction}

Artificial induction of labour has increasingly become part of modern obstetric practice (see table I). But there are sharply conflicting views on the value of induction in reducing perinatal mortality and morbidity, ${ }^{1-,}$ however, and O'Driscoll and Stronge have suggested that the emotional stress of induction on the mother is often gravely underestimated. ${ }^{6}$ As planned induction of labour is often undertaken for medical reasons and as the value of intervention in certain cases is now under considerable debate among obstetricians, it seemed opportune to evaluate patients' attitudes towards this practice.

Aspects of modern obstetrics are freely debated in the media, so patients should be better informed about current obstetric trends and may have preformed opinions on the management of their pregnancy. I therefore attempted to determine patients' views on their labour with particular reference to planned inductions but also including other aspects that have recently received publicity in the lay press. It was hoped that the information so obtained could be used to guide future obstetric practice in this unit for the benefit of both patients and staff.

\section{Methods}

All patients booked for delivery in the Nuneaton Maternity Hospital are invited to attend mothercraft classes, and at about 28 weeks' gestation they are shown round the labour ward, and induction of labour and the various methods of delivery are discussed. In 1976 $34.6 \%$ of labours in this unit were induced; this is comparable to the rate in other hospitals (table I). All but three of the patients who had 
TABLE I-Incidence of induced labours in the 1960s and 1970s in various centres

\begin{tabular}{|c|c|c|c|c|c|c|c|c|}
\hline \multirow[t]{2}{*}{ Centre: } & \multicolumn{2}{|c|}{ Glasgow4 } & \multicolumn{2}{|c|}{ Liverpool $^{\mathrm{s}}$} & \multicolumn{2}{|c|}{ Oxford ${ }^{3}$} & \multicolumn{2}{|c|}{ Cardiff $^{1}$} \\
\hline & 1966 & 1975 & 1960 & 1973 & 1965 & 1972 & 1965 & 1973 \\
\hline Incidence $\left({ }^{0}{ }_{11}\right)$ & $16 \cdot 3$ & $35 \cdot 6$ & $19 \cdot 8$ & 33.9 & $22 \cdot 2$ & $35 \cdot 7$ & $7 \cdot 5$ & $26 \cdot 5$ \\
\hline
\end{tabular}

a planned induction of labour between 8 November 1976 and 6 February 1977 were included in the study. One patient was excluded because she had a known anencephalic fetus, one because she had a known intrauterine death, and the third because of an unexplained stillbirth.

If they were not already inpatients the patients were admitted to the antenatal ward the day before induction. On the morning of induction, $50 \mathrm{mg}$ pethidine and $50 \mathrm{mg}$ promazine were given orally as predmedication one hour before transfer to the labour ward. Four methods of induction were used depending on the circumstances of the individual patient (table II). All amniotomies were forewater ruptures. "Automatic" oxytocic infusion was carried out using a Cardiff infusion pump and all other oxytocic infusions were regulated by Tekmar drip regulator. Intravenous prostaglandins were not used.

TABLE II-Methods of induction used

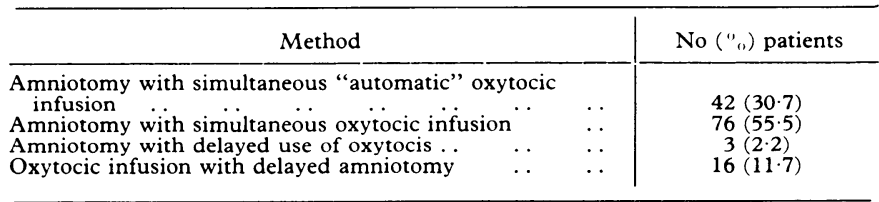

The method was usually decided by the resident labour ward staff, but in certain circumstances the consultant in charge of the patient made the decision. After induction the patients remained in a normal hospital bed throughout the first stage of labour. An epidural anaesthetic service is available in the unit for selected cases. Only one patient specifically requested this type of pain relief.

Within the 24 hours before their induction the patients were questioned about any knowledge of induction that they had acquired before this pregnancy, how the subject had been broached in this pregnancy and by whom, and whether they thought that they had been given enough information. They were also asked whether they had agreed to the induction gladly, indifferently, or reluctantly or whether they had initially refused, and they were asked to amplify on their answer. While in labour, they were asked about their immediate reactions to the induction-both to the amniotomy and the setting up of the intravenous infusion. Within 12 hours of delivery they were questioned about their attitude to the labour with particular reference to their analgesic requirements, the use of electronic equipment, and whether or not they would have preferred to be ambulant during the first stage. After a further 48 hours they were asked whether they would like to amend any of their previous answers to the questions about induction and labour having had a little more time to reflect. Al questioning was carried out by three midwives to try to achieve reasonable uniformity.

For each patient a record was kept of the method of induction, modified Bishop's score of the cervix at the time of induction, the induction-to-delivery interval, type of delivery, and the equipment used during labour. Two patients received lumbar epidural anaesthesia, eight received no analgesia other than their premedication, and the rest had intramuscular injections of narcotic drugs with sedatives and inhalation analgesia.

\section{Results}

Altogether 140 patients were questioned; but three questionnaires were found to be incomplete and so were discarded. Of the 137 patients included in the analysis 55 were primiparous patients and 82 multiparous. The indications for induction are given in table III. There was no serious maternal morbidity among the patients, and the three perinatal deaths were excluded as explained above. Only one patient failed to go into labour after an attempt at induction. She was ultimately delivered by lower segment caesarean section 48 hours after the start of oxytocic infusion and 20 hours after amniotomy. Of the three other patients delivered by caesarean section two failed to progress adequately in labour: one had had a previous abdominal delivery and had only reached a dilatation of $3 \mathrm{~cm} 24$ hours after amniotomy and simultaneous infusion of syntocinon $(5 \mathrm{IU} /$ litre at $20 \mathrm{drops} / \mathrm{min}$ ); the other patient reached a similar dilatation after 48 hours of intravenous syntocinon and 24 hours after amniotomy, but she had been in labour for less than 20 hours. There were five forceps deliveries, four vacuum extractions, and six breech deliveries.

TABLE III-Indications for induction

\begin{tabular}{|c|c|c|c|}
\hline Induction & & & No $\left({ }^{\prime}{ }_{0}\right)$ of patients \\
\hline $\begin{array}{l}\text { Hypertension or pre-eclampsia } \\
\text { Overdue by dates } \\
\text { Evidence of placental insufficiency } \\
\text { Evidens. } \\
\text { Twins. } \\
\text { Breech } \\
\text { Others, including antepartem haemorrhage }\end{array}$ & $\begin{array}{l}\cdots \\
\cdots \\
\cdots \\
\cdots\end{array}$ & $\begin{array}{l}\cdots \\
\cdots \\
\cdots \\
\cdots\end{array}$ & $\begin{aligned} & 53(38 \cdot 7) \\
& 32(23 \cdot 4) \\
& 25(18 \cdot 3) \\
& 3(2 \cdot 2) \\
& 6(4 \cdot 4) \\
& 18(13 \cdot 1)\end{aligned}$ \\
\hline
\end{tabular}

Table IV shows the sources of the information on induction that patients had obtained before the present pregnancy and table $\mathrm{V}$ shows the opinions formed. Of the 30 patients who had not heard of induction before their pregnancy, 13 learnt about it at mothercraft classes, three from other patients, two from reading books, and 22 from doctors either in the antenatal clinic or in the antenatal ward. During the pregnancy 14 patients were told of the possibility of their induction early in the pregnancy and the reaminder within the few days before delivery. Most patients (106) were informed of the planned induction of labour by the consultant in charge of the case, 28 were informed by a junior doctor, and three were told by a nurse. Forty-four patients thought that they were not given enough information about the reason for their induction, and 63 claimed that they were not given enough

TABLE IV-Source of information on induction before this pregnancy

\begin{tabular}{|c|c|c|c|c|c|}
\hline & & & & $\begin{array}{l}\text { No of } \\
\text { primiparous } \\
\text { women }\end{array}$ & $\begin{array}{c}\text { No of } \\
\text { multiparous } \\
\text { women }\end{array}$ \\
\hline $\begin{array}{l}\text { Relatives or friends ... } \\
\text { Newspapers or television } \\
\text { Hospital . . . . } \\
\text { Cannot remermber . } \\
\text { Never heard of induction } \\
\text { Previous induction... }\end{array}$ & $\begin{array}{l}\because \\
\because \\
\cdots \\
\cdots\end{array}$ & $\begin{array}{l}\cdots \\
\cdots \\
\cdots \\
\cdots \\
\cdots\end{array}$ & $\begin{array}{l}\cdots \\
\cdots \\
\cdots \\
\cdots \\
\cdots\end{array}$ & 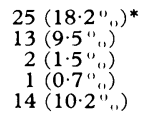 & 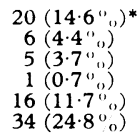 \\
\hline
\end{tabular}

*Percentages are of total group of women (137).

TABLE $\mathrm{V}-O$-Opinions formed on induction before this pregnancy

\begin{tabular}{|c|c|c|c|}
\hline & & $\begin{array}{l}\text { No of } \\
\text { primiparous } \\
\text { women }\end{array}$ & $\begin{array}{l}\text { No of } \\
\text { multiparous } \\
\text { women }\end{array}$ \\
\hline 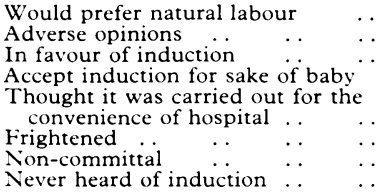 & $\begin{array}{l}\cdots \\
\cdots \\
\cdots \\
\cdots \\
\cdots \\
\cdots\end{array}$ & 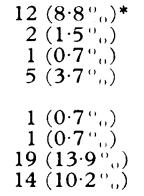 & $\begin{array}{c}14\left(10 \cdot 2^{\circ}{ }_{0}\right)^{*} \\
2\left(1 \cdot 5^{\prime \prime}{ }^{*}\right) \\
13\left(9 \cdot 5^{\prime \prime}\right)\end{array}$ \\
\hline
\end{tabular}

*Percentages are of total group of women (137).

TABLE VI-Patients' attitudes towards their own inductions

\begin{tabular}{l|l|c}
\hline \multicolumn{1}{c|}{ Attitude } & \multicolumn{1}{|c}{ Comment } & $\begin{array}{c}\text { No("., of } \\
\text { patients }\end{array}$ \\
\hline Glad & $\begin{array}{l}\text { Glad to end pregnancy } \\
\text { Accept it for baby's benefit }\end{array}$ & $91(66 \cdot 4)$ \\
& $\begin{array}{l}\text { Relieved to know outcome } \\
\text { (previous stillbirth) }\end{array}$ & $1(0 \cdot 7)$ \\
Indifferent & Prefer natural labour & $10(7 \cdot 3)$ \\
& Nervous & $1(0 \cdot 7)$ \\
Reluctant & No further comment & $11(8 \cdot 0)$ \\
& Prefer natural labour & $12(8 \cdot 8)$ \\
& Previous bad experience with induction & $3(2 \cdot 2)$ \\
\hline
\end{tabular}


TABLE VII-Patients' descriptions of methods of induction

\begin{tabular}{|c|c|c|}
\hline & Amniotomy & $\begin{array}{l}\text { Setting up of } \\
\text { intravenous } \\
\text { infusion }\end{array}$ \\
\hline $\begin{array}{l}\text { Painful } \\
\text { Uncomfortable } \\
\text { Frightening } \\
\text { Indifferent }\end{array}$ & $\begin{array}{l}20(14 \cdot 6) \text { (including } 1 \text { failed amniotomy) } \\
72(52 \cdot 6) \\
7(5 \cdot 1) \\
38(27 \cdot 7) \text { (including } 15 \text { delayed } \\
\text { amniotomies) }\end{array}$ & $\begin{array}{l}13(9 \cdot 5) \\
74(54 \cdot 0) \\
2(1 \cdot 5) \\
48(35 \cdot 0)\end{array}$ \\
\hline
\end{tabular}

information about the method. Tables VI and VII show patients' reactions to their own inductions and to the method of induction.

The range of Bishop's score of the cervix at amniotomy in all patients except those with a delayed amniotomy was $2-12$ with a mean $(t S D)$ of $6.67+0.953$. The mean for those patients who described amniotomy as painful was $6.05 \pm 0.9780$, and for those who found it merely uncomfortable or were indifferent it was $6 \cdot 78 \pm 0.960$. This difference was significant $(\mathbf{P}<0.01)$. Most amniotomies were carried out by five senior house officers. There was no correlation between the doctor who carried out the procedure and the patients' comments. Most patients were non-commital about the electronic equipment used during their labours, though seven found it interesting, four disturbing, and three frightening because not enough explanation was given, and three were frightened by the fact that the equipment did not appear to be working properly.

In reply to the other questions asked at the delivery only 20 patients said that they would have preferred to have been ambulant during the first stage of labour. Table VIII summarises the replies to questions on the duration of labour, the amount of pain experienced, and analgesic requirements. The mean induction-to-delivery interval of all patients, including one patient who was never in estaolished labour, was $7 \cdot 605 \pm 4 \cdot 14$ hours (table IX). The difference in mean intervals between those with adequate analgesia and those without was not significant. Ten primiparous and 17 multiparous patients complained of inadequate analgesia.

TABLE VIII-Patients' assessments of actual labour compared with what they had expected

\begin{tabular}{|c|c|c|c|}
\hline & Greater & Less & As expected \\
\hline $\begin{array}{l}\text { Duration of labour } \\
\text { Pain of labour } \\
\text { Analgesic requirements }\end{array}$ & $\begin{array}{l}48(35 \cdot 0) \\
62(45 \cdot 2) \\
27(19 \cdot 7)\end{array}$ & $\begin{array}{r}82(60 \cdot 0) \\
71(51 \cdot 8) \\
109(79 \cdot 6)\end{array}$ & $\begin{array}{l}7(5 \cdot 0) \\
4(3) \\
1(0 \cdot 7)\end{array}$ \\
\hline
\end{tabular}

TABLE IX-Induction to delivery intervals

\begin{tabular}{|c|c|c|c|c|c|c|}
\hline Induction-delivery interval $(\mathrm{h})$ : & $0-2$ & 6 & 10 & 14 & $>14$ & $\underset{\text { (h) }}{M e a n}$ SD \\
\hline $\begin{array}{l}\text { All patients } \\
\text { Patients with inadequate analgesia } \\
\text { Patients with adequate analgesia }\end{array}$ & $\begin{array}{l}6 \\
5 \\
1\end{array}$ & $\begin{array}{r}55 \\
6 \\
49\end{array}$ & $\begin{array}{r}35 \\
4 \\
31\end{array}$ & $\begin{array}{l}30 \\
10 \\
20\end{array}$ & $\begin{array}{r}11 \\
2 \\
9\end{array}$ & $\begin{array}{l}7 \cdot 605=4 \cdot 14 \\
7.884 \div 4 \cdot 9 \\
7 \cdot 536=3.94\end{array}$ \\
\hline
\end{tabular}

When questioned 48 hours after delivery most patients considered that the whole process of induction and labour was better than they had expected. Five, however, complained that labour was too rapid, and five who compared their labour with a previous delivery said that the contractions were much more painful with oxytocic stimulation. Of the 11 patients with induction-to-delivery intervals greater than 14 hours, three specifically said that they thought that their prolonged labour was due to a relatively inactive approach to the management of their labour.

\section{Discussion}

Any survey from which it is hoped to make an accurate analysis necessitates the use of direct questioning and a limited choice of reply. The alternative approach of allowing the responder complete freedom of reply produces difficulties in analysing results. This survey used a mixed approach. As each pregnancy and labour is handled as an individual case, absolute uniformity of management is in any case impossible. Despite these reservations some information of value was obtained.

Despite the considerable amount of publicity given to the maternity services in Britain, one in five pregnant women undergoing induction, including multigravidae, had not heard of induction before their pregnancy. Of those who had, most had gained the information, as expected, from relatives and friends, with $14.7^{\circ}$ acquiring their knowledge through the media. Only $1 \cdot 5^{\circ}$ o had actively adverse opinions, however, although $24^{\circ}$ o would have preferred a natural labour. Only 13 of the 30 patients who had no knowledge of induction before their pregnancy obtained their information at mothercraft classes, and although the majority did eventually learn about it from medical sources an improved attendance at antenatal classes would help to fill this gap. Three patients learnt about their own planned induction from a nurse rather than from a doctor from the firm looking after the patient. Although this is a small number, communication of such an important event in the management of the pregnancy should not be left to nursing staff.

Tables $\mathrm{V}$ and VI show an interesting difference in patients' attitudes towards induction per se and their own forthcoming induction. Although the number of patients preferring a natural labour was similar, many patients were pleased that their own pregnancy was to be ended, despite possibly having reservations about induction. This attitude was not apparent when patients were asked to consider induction that was not directly related to themselves. A very high proportion of patients did, however, claim that they were not given enough information about the reason for and the method of their induction. Medical staff should beware of assuming that because they know how the pregnancy is going to be managed so does the patient. The simple matter of deliberately asking patients whether they have any queries could help to eliminate many patients' misunderstandings.

As might be expected, the patients who found amniotomy painful tended to have a lower Bishop's score of the cervix. When assessing a patient for induction it would be valuable to determine the "ripeness" of the cervix as well as the parity and the overall attitude of the patient before deciding on the amount of premedication required. Those patients known to have a lower cervical score could also be given inhalation or other forms of analgesia before attempting amniotomy.

Patients' reactions to the electronic equipment used in the labour ward were very favourable. Perhaps the close contact between midwife and patient which occurs during the course of labour encourages fuller explanations.

The patients were asked about ambulation during the first stage of labour because of recent reports of complex equipment being installed in maternity units to enable patients to move about during the early stage of labour while still being monitored.' There may be advantages in patients being ambulant, but only a few of our patients would have preferred more mobility in the first stage of labour.

Although nearly half of the patients considered that labour was more painful than they expected only 27 actually said that analgesia was inadequate. This suggests that some patients expect their labours to be very painful and those managing labour should beware of failing to give needed analgesia to the more stoical patient. Each labour must be taken as an individual case and therefore no rigid regimen of pain relief should be used. Nevertheless, with a few experienced midwives supervising each labour a reasonably uniform approach may be achieved. Table IX shows that of those patients who considered analagesia inadequate a disproportionately high number had short (less than two hours) induction-to-delivery intervals or intervals of 10 to 14 hours. This second group might have benefited from a more liberal use of the epidural anaesthesia service. The first group, however, presents a more difficult problem. All patients were given oral pethidine before induction, so the problem of what further analgesia to give in a very short labour is a difficult one. With delivery expected within the hour, only inhalation analgesia may be tried, but it may be inadequate. By postponing the 
decision to give further narcotics the drugs may well be given too late to have any effect on the mother, although if given slightly earlier, and if delivery does occur within the next one to two hours, the baby may be affected and the start of his respiration impaired. For patients who are progressing rapidly in labour after induction and who can be expected to deliver within two to three hours from the time of induction a totally satisfactory form of analgesia does not appear to be available. The use of a relatively new form of analgesia, transcutaneous nerve stimulation, ${ }^{\circ}$ may be of value in this situation, and we are currently evaluating this method. It is interesting to note that six patients in the two-to-six hour group received no analgesia other than premedication and considered this quite adequate.

I thank sisters L Green and C McColl and staff midwife C Davis for questioning the patients, and Mr V G Kenyon and Mr M L Cox for permitting patients under their care to be included in the survey.

\section{References}

${ }^{1}$ Chalmers, I, et al, British Medical fournal, 1976, 1, 735.

${ }^{2}$ Chalmers, I, et al, British fournal of Obstetrics and Gynaecology, 1976, 83, 930.

${ }^{3}$ Fedrick, J, and Yudkin, P, British Medical fournal, 1976, 1, 738.

${ }^{4}$ McNay, M B, et al, British Medical fournal, 1977, 1, 347.

5 Alderman, B, Clinics in Obstetrics and Gynaecology, 1975, 2, 44.

${ }^{6}$ O'Driscoll, K, and Stronge, J M, Clinics in Obstetrics and Gynaecology, $1975,2,5$.

'Flynn, A, and Kelly, J, British Medical fournal, 1976, 2, 842.

${ }^{8}$ Augustinsson, L-E, et al. In press.

(Accepted 12 August 1977)

\title{
Letter from . . Chicago
}

\section{Jet lag science}

\author{
GEORGE DUNEA
}

British Medical fournal, 1977, 2, 752-753

At the southern end of the Monterey Peninsula stands Carmelby-the-Sea, a small picturesque town that slants to a greyishwhite beach and a foaming surf. Just north is Pebble Beach, the golfer's paradise, and then the 17-mile drive to Monterey -one of California's most scenic routes. The town is quiet and unspoiled, with low-set wooden houses half-hidden by surrounding shrubbery, with ferns and cypresses lining the streets, and with a sprinkling of eucalyptus. There are no neon lights, no garish signs, but, for the tourists, art galleries and bookstores, elegant shops and fine restaurants, open air cafes, and even espresso bars. The sun shines warmly here, at a time when most of America is frozen and snowbound; and it is in these idyllic surroundings that the western sections of the three societies for biomedical research hold their annual meeting.

There is much to be said for skipping the scientific sessions and walking among the trees or along the beach. But once this temptation is overcome and the decision is made to educate oneself, one may admire slides of polymerising haemoglobin-S molecules, of naughty gonococci that have become resistant to penicillin, of complex diagrams explaining cholesterol transport and intimal damage, and the role of high-density lipoproteins. Hodgkin's disease in 1977 has an excellent prognosis, and the treatment with radiation and chemotherapy is complicated and successful. Potassium-depleted rats increase their water intake before they develop polyuria and impaired urinary concentrating ability. Idiopathic hypercalciuria is a compensatory response to a renal phosphate leak-one expert claims, and another shakes his head in dissent. Hydrallazine and other vasodilators reduce cardiac afterload and may help

Cook County Hospital, Chicago, Illinois 60612

GEORGE DUNEA, MB, FRCPED, attending physician some forms of heart failure. Clonidine suppresses catecholamine release and prevents certain types of flushing. Patients taking phenytoin need twice as much prednisone to achieve an equivalent therapeutic effect. Gallium scans are good for studying the response of Paget's disease to calcitonin. Patients with $\alpha_{1}$-antitrypsin deficiency have basal as well as apical lung scan defects and no $\alpha_{1}$-globulin peaks on electrophoresis; not smoking stops the endoproteases from digesting the alveoli; and the trouble lies with the hepatocytes' failure to release the $\alpha_{1}$-antitrypsin granules.

The most exciting presentation, however, was Dr Roger Guillemin's on the peptides of the hypothalamus. Starting with the observation that the human brain had receptors for opiate alkaloids and with the surmise that these receptors might be concerned with the perception of pain, he found it a simple matter to grind up a quarter of a million pig hypothalamuses and neurohypophyses; carry out a series of elaborate separation procedures; determine which fraction was biologically active; and isolate several "endorphin" peptides that have opiate-like activity. These endorphin peptides and the related enkephalins fit together like a jigsaw puzzle into a 90 amino-acid $\beta$-lipotropin, a pituitary extract long in search of a function, and are stored in the pars intermedia, also long in search of a function. And then it was shown that various endorphins, when injected into rats, can make them depressed or catatonic, agitated or tranquillised-thus raising the hope that some day we may learn what makes people psychotic, or addicted, or tolerant to various drugs.

\section{Hypertension}

Next, we find ourselves walking through the narrow streets of old San Juan, admiring the magnificent El Convento Hotel or the solid stone El Moro fortress guarding the entrance to the harbour-or we might leave for Puerto Rico's fashionable 